\title{
Efficacy of AlCl3 and ethanol in the prevention of calcification of fragments of porcine aortic wall fixed in GDA
}

\author{
Eficácia do AlCl3 e etanol na prevenção da calcificação de fragmentos da parede aórtica porcina \\ fixados em GDA
}

Evandro Antonio SARDETO ${ }^{1}$, Francisco Diniz Affonso da COSTA², Iseu do Santo Elias Affonso da COSTA³, João Gabriel RODERJAN ${ }^{4}$, Eduardo DISCHER ${ }^{5}$, Ricardo Alexandre SCHNEIDER ${ }^{1}$, Carlos Henrique Gori GOMES $^{6}$, Claudinei COLATTUSSO ${ }^{6}$, Daniel PRÉCOMA ${ }^{7}$, Andrea DUMSCH ${ }^{1}$, Sergio Veiga LOPES ${ }^{1}$, Jairo LEAL $^{6}$

\section{Abstract}

Objective: To evaluate the efficiency of aluminum chloride in isolation or associated with ethanol to prevent calcification and inflammatory reaction with fragments of porcine aortic wall fixed in glutaraldehyde (GDA) and subdermally implanted in young rats.

Method: Fifteen Sprague-Dawley rats were studied. Three fragments of porcine aortic wall were implanted in the subdermal tissue. The fragments were previously subjected to three different methods of treatment: I (GDA), II (GDA + aluminum), III (GDA + ethanol + aluminum). Explantation was performed after fifteen, thirty and sixty days. Histological analysis was achieved using hematoxylin \& eosin (HE) and alizarin-red at pHs of 4.2 and 7.0. Calcium content was determined by atomic absorbance spectroscopy.

Results: HE and alizarin red staining showed that the aortic wall extracellular matrix was best preserved in the

1 - MSc; Heart Surgeon

2 - Livre docente in surgery; Head of Heart Surgery in Santa Casa of Curitiba

3 - Livre docente in surgery; Heart Surgeon

4 - Biochemist; MSc; Pharmacist

5 - Biologist

6 - Resident of Heart Surgery

7 - Resident of Cardiology

Work carried out in the Pontifícia Universidade Católica of Paraná. Curitiba, Brazil

Correspondence address:

Evandro Antonio Sardeto. Rua Guido Straube, 653 - apto 604. Edifício

Vicenza. Vila Izabel - Curitiba, PR, Brazil - CEP 80320030

E-mail: evandro_sardeto@uol.com.br fragments of Group III. The intensity of the inflammatory reaction was lower in this group. When stained with alizarin red at pH 4.2, Groups II and III had lower degrees of calcification compared with Group I. With alizarin red staining at pH 7.0, Group III demonstrated less calcification compared with Groups I and II. Atomic absorbance spectroscopy showed similar calcium levels for both Groups II and III, but significantly less than in Group I.

Conclusion: Treatment with aluminum chloride inhibits calcification of fragments of aortic wall after implantation and reduces inflammatory reaction. The combined use of ethanol with aluminum chloride is more efficient to inhibit calcification and also to diminish inflammatory reaction.

Descriptors: Aorta. Calcification, physiologic. Ethanol. Aluminum compounds, pharmacology.
Article received in June, 2006 Article accepted in October, 2006 


\section{Resumo}

Objetivo: Avaliar a eficácia do cloreto de alumínio, isoladamente ou em associação com o etanol, na prevenção da calcificação e da resposta inflamatória de fragmentos de parede aórtica porcina fixada em glutaraldeído (GDA), implantados no tecido subcutâneo de ratos jovens.

Método: Utilizaram-se 15 ratos da linhagem SpragueDawley, em cujas telas subcutâneas foram implantados fragmentos de parede aórtica porcina, submetidos a três diferentes métodos de tratamento [grupos: I (GDA), II (GDA+alumínio), III (GDA+etanol+alumínio)]. Os explantes foram realizados com 15, 30 e 60 dias após as operações. Foram realizadas análises histológicas pelas colorações de hematoxilina \& eosina (HE) e de alizarina, nos pHs de 4,2 e 7,0, e a dosagem de cálcio feita por espectroscopia de absorção atômica.

Resultados: Pelo HE, constatou-se que a matriz

\section{INTRODUCTION}

Nowadays heart valve replacement with prostheses is a routine procedure. However, despite all the technical developments, an ideal valve substitute is not available yet.

There are two basic types of prostheses: biological and mechanical. Biological prostheses present with a good hemodynamic performance and are associated with a low rate of thromboembolic phenomena even without anticoagulation therapy. Their greatest disadvantage is the limited durability particularly in children and young patients in whom degeneration by calcification starts early.

On the other hand, mechanical prostheses are durable, but present with a high incidence of thromboembolic events and require permanent systemic anticoagulation. In populations with low socioeconomic conditions such as in Brazil, the difficulties involved in maintaining effective anticoagulation significantly limit their use.

Biological tissues have been utilized as valve substitutes since 1962 when a fresh human aortic valve was transplanted [1]. From then on, several biological substitutes have been tested. At the end of the 1960s there was an important development when Carpetier et al. [2] introduced glutaraldehyde (GDA) in the fixation process of porcine prostheses. Ionascu et al. [3] in the 1970s presented a bovine pericardium valve preserved in GDA. In Brazil, Braile et al. [4] were responsible for the development of bovine pericardium prostheses preserved in GDA.

The success of GDA as a fixer of biological tissues in extracelular das paredes aórticas ficaram melhor preservadas nos explantes do grupo III. A intensidade da reação inflamatória intensa foi menor nesse grupo. Pela alizarina pH 4,2, o grupo II e III tiveram menores índices de calcificação comparado ao controle. Pela alizarina pH 7,0, o grupo III teve menor índice de calcificação comparado aos grupos I e II. Pela espectroscopia de absorção atômica, os níveis de cálcio foram semelhantes para os grupos II e III, mas significativamente menores do que os do grupo $\mathrm{I}$.

Conclusão: O tratamento com cloreto de alumínio diminuiu a calcificação dos fragmentos de parede aórtica porcina. $O$ uso combinado do etanol com cloreto de alumínio foi ainda mais eficiente em inibir a calcificação, e também em diminuir a reação inflamatória.

Descritores: Aorta. Calcificação fisiológica. Etanol. Compostos de alumínio, farmacologia. valve substitutes was due to its efficacy if stabilizing the tissue, significantly reducing the antigenicity of the tissue as well as being a sterilizing agent. However, more recently, GDA has been implicated as a facilitator of calcification observed over the long term in valve prostheses [5].

With the aim of improving the durability of biological prostheses, several anti-calcification treatments have been tested with differing degrees of success [6,7]. Among these, ethanol and aluminum chloride were proved capable of delaying the calcification process both in animal and human models.

Previous studies performed in the Experimental Surgery Laboratory of PUC-PR demonstrated that, both in a subcutaneous model using rats and in sheep circulation, ethanol was efficient to prevent calcification of porcine valve cuspids previously fixed in GDA. However, this did not occur with the aortic artery wall [8].

The objective of this study was to evaluate aluminum chloride in isolation and aluminum chloride associated with ethanol in the prevention of calcification and inflammatory response of fragments of porcine aortic wall fixed in GDA when subcutaneously implanted in young rats.

\section{METHOD}

This work was performed in the Laboratories of Experimental Surgery and Operative Technique of the Pontifícia Universidade Católica in Paraná (PUC-PR), of Cardioprótese Ltda. of Experimental Pathology da PUC-PR 
and in the Technology Institute for Development (LACTEC).

The Ethics Research Committee on Animal Research of PUC-PR approved this experiment.

All the aortic valve prostheses (Cardioprótese ${ }^{\circledR}$ ) were previously fixed in $0.5 \%$ GDA in a phosphate buffer solution with a $\mathrm{pH} 7.4$ for 72 hours at room temperature (standard fixing). After the initial fixing, the valves were distributed in three distinct groups according to the additional chemical treatment (Table 1).

Table 1. Treatment of porcine aortic valves in the different groups.

\begin{tabular}{|c|c|c|c|}
\hline Group & $\begin{array}{l}\text { Tissue fixation } \\
\text { (Time I) }\end{array}$ & $\begin{array}{c}\text { Additional } \\
\text { treatment (Time II) }\end{array}$ & $\begin{array}{l}\text { Estorage } \\
\text { (Time III) }\end{array}$ \\
\hline I & $\begin{array}{l}\text { GDA } 0.5 \% \\
\text { for } 72 \text { hours }\end{array}$ & - & $0.2 \%$ GDA \\
\hline II & $\begin{array}{l}\text { GDA } 0.5 \% \\
\text { for } 72 \text { hours }\end{array}$ & $\begin{array}{l}0.1 \mathrm{M} \mathrm{AlCl} 3 \text { at } \mathrm{pH} 3.0 \\
\text { for } 105 \mathrm{~min}\end{array}$ & SSI \\
\hline III & $\begin{array}{l}\text { GDA } 0.5 \% \\
\text { for } 72 \text { hours }\end{array}$ & $\begin{array}{l}\text { 80\% Ethanol } 24 \text { hours } \\
+0.1 \mathrm{M} \mathrm{AlCl} 3 \text { at } \mathrm{pH} 3.0 \text {, } \\
\text { for } 105 \mathrm{~min}\end{array}$ & SSI \\
\hline
\end{tabular}

The valves of Group I (Control Group) received the conventional treatment employed with commercially available bioprostheses, that is, after the initial fixing with $0.5 \%$ GDA they were kept in buffered solutions with $0.2 \%$ GDA until implantation.

The valves in Groups II and III, after the initial fixing with $0.5 \% \mathrm{GDA}$, were placed in sterile glass flasks and rinsed in $500 \mathrm{~mL}$ of $0.9 \% \mathrm{NaCl}$ saline solution (SSI) for 15 minutes at $37^{\circ} \mathrm{C}$ under continuous stirring (Shaker-Quimis-Q225M) of $1700 \mathrm{rpm}$ repeating the rinsing three times to completely remove residual GDA.

After rinsing, the valves of Group II were treated in 0.1 $\mathrm{M} \mathrm{AlCl} 3$ solution at $\mathrm{pH} 3.0$ in a sterile glass flask for 105 minutes under stirring of $1700 \mathrm{rpm}$ at $37^{\circ} \mathrm{C}$ with replacement of solution after 50 minutes and stored in SSI.

The valves of Group III were treated in $80 \%$ ethanol for 24 hours followed by treatment in $0.1 \mathrm{M} \mathrm{AlCl} 3$ at $\mathrm{pH} 3.0$ during 105 minutes under stirring of $1700 \mathrm{rpm}$ at $37^{\circ} \mathrm{C}$ with exchange of the solution after 50 minutes and were also stored in SSI.

After completing the chemical treatment, quadrangular segments of arterial wall measuring approximately $0.5 \mathrm{~cm}^{2}$ with a thickness of 4 to $6 \mathrm{~mm}$ removed from the ascending aorta were obtained immediately above the sinotubular junction.

Fifteen 21-day-old rats (Ratus norvergicus) from the Sprague-Dawley linage were utilized. Their weights varied between 50 and 70 grams. They were divided into three groups of five animals (I, II, III) according to the type of chemical treatment of the fragments of porcine aortic wall as shown in Table 2.

Table 2. Distribution of rats in groups

\begin{tabular}{lcc}
\hline Grupos & Treatment & Time \\
\hline & & 15 days $-\mathrm{L}$ \\
I & 30 days $-\mathrm{TL}$ \\
& 60 days $-\mathrm{S}$ \\
& & \\
& & 15 days $-\mathrm{L}$ \\
II $\quad$ GDA +ALUMINUM n=5 & 30 days $-\mathrm{TL}$ \\
& & 60 days $-\mathrm{S}$ \\
& & 15 days $-\mathrm{L}$ \\
& & 30 days $-\mathrm{TL}$ \\
III $\quad$ GDA+ALUMINUM+ETHANOL $\mathrm{n}=5$ & 60 days $-\mathrm{S}$ \\
& &
\end{tabular}

GDA - Glutaraldehyde; L - Lumbar; TL - Thoracic-lumbar; S scapular

Three segments of aortic wall were implanted in each animal as illustrated in Table 1, with one implanted in the lumbar region $(\mathrm{L})$ one in the thoraco-lumbar region (TL) and one in the scapular region (S). The fragments were subsequently explanted at 15, 30 and 60 days, respectively.

After the last explantation, the animals were sacrificed induced by carbon dioxide gas in a glass desiccator connected to a $\mathrm{CO}_{2}$ cylinder.

The explanted aortic fragments were split in two. Slides were produced for histopathologic examination from the first part and the second was weighed and utilized for the measurement of calcification by atomic absorption spectrometry.

The structures of tissues (extracellular matrix) and inflammatory infiltration were observed on the slides stained using $\mathrm{HE}$ as were possible histological alterations that might show calcification.

For this study, we arbitrarily created a classification system for the measurement of inflammatory infiltration which was thus divided: 0 - absence, 1 - light to moderate, 2 - intense (Table 3).

Table 3. Classification of the inflammatory infiltrates

\begin{tabular}{ll}
\hline Type & Intensity \\
\hline 0 & Absence \\
1 & mild and moderate \\
2 & Intense \\
\hline
\end{tabular}


Apart from HE staining, the samples were stained with alizarin at $\mathrm{pH} 4.2$ (specific to identify phosphate crystals and calcium carbonate) and with alizarin at $\mathrm{pH} 7.0$ (specific to identify crystals of calcium oxalate) for the detailed analysis of the calcification pattern. The calcification observed on the slides stained with alizarin was evaluated by morphometric analysis. Assessments were made by the analysis of three areas on each slide: left upper corner (LUC), center (C) right lower corner (RLC). Utilizing the function of counting and comparison of classes, an analysis of the tissues was made resulting in a percentage of calcified tissue for each studied field.

All the characteristic structures and those stained for calcification were marked in green. All the non-calcified tissues were marked in yellow. To establish a percentage of calcified tissue, the arithmetic mean of the three fields on the same slide was calculated.

Samples of the aortic wall were dissolved in a $50 \%$ chloride acid solution and sent to the Laboratories of the Development Institute (LACTEC-PR0) to determine the quantity of calcium.

\section{Statistical analysis}

The analyzed variables were calcium content by atomic absorption spectrometry and the data on the morphology. To analyze inflammatory infiltration, Types 0 and 1 were included in one group with the other group consisting of Type 2 infiltrates.

For the analysis of calcification variables, the groups wee compared using the non-parametric Kruskal-Wallis test. The evaluation of the effect of time was achieved comparing the different evaluation times. For this, the non-parametric Friedman test and the non-parametric test of Wilcoxon for multiple comparisons were utilized.

To compare the variables related to inflammatory infiltration among the groups the Fisher exact test was used and to compare the different evaluation instances, the binomial test was used. A level of significance of $0.5 \%$ was adopted (p-value $<0.05$ ). In the multiple comparisons, the Bonferroni correction was employed ( $p$-value $<0.0167$ indicating statistical significance) thereby maintaining the overall level of significance at 0.05 .

\section{RESULTS}

There was one death in the immediate postoperative period of one animal of the Control Group due to hypoxia. The others had a good evolution and the explantations were performed on the designated days.

\section{Analysis of the inflammatory infiltrates and extracellular matrix fibers}

\section{Group I}

At 15 days there was chronic inflammatory infiltration seen by the presence of mononuclear cells. The fibers of the extracellular matrix remained integral and with preservation of the original organization, maintaining their original orientation and the proximity to each other, without evidence of rupture or separation. At 30 days however, the infiltration was more intense, advancing to the center of the implants. The fibers of the extracellular matrix continued with their original organization however, rupture of some fibers was seen in the areas with greatest contact with the inflammatory infiltrate. At 60 days, the inflammatory infiltrates had penetrated much further to the center of the implants with great damage to the tissue.

\section{Group II}

At 15 days the presence of mononuclear cells was observed characterized by chronic inflammation. The organization of the fibers of the extracellular matrix was preserved. Even fibers in contact with the inflammatory infiltrate remained intact. At 30 days, even in the presence of inflammatory reaction, there was no advance of these cells inside the implants. The organizational integrity of the fibers of the extracellular matrix persisted. At 60 days, the mononuclear cells continued to be present, although, unlike what happened in Group I, there was no evidence of damage to the extracellular matrix fibers.

\section{Group III}

At 15 days, unlike the two previous groups, inflammatory cells were not observed. The fibers of the extracellular matrix remained organized without structural damage. At 30 days, inflammatory infiltration was still not evidenced. The fibers of the extracellular matrix continued unchanged. No signs of calcification were observed. Even at 60 days, inflammatory reaction was not identified. The fibers preserved their original organization, but in some implants it was possible to see small areas of rupturing, where small aggregates were visible in the form of crystals that may indicate the beginning of the calcification process (Figure 1).

\section{Quantitative analysis of the inflammatory infiltration of the conducts}

Results of the measurement of the inflammatory reaction caused by the aortic wall specimens of the three groups are shown in Figure 2.

It was evident that the aortic walls of Group III caused less intense inflammatory reaction when compared to Groups I and II.

When assessed from a statistical point of view, there was no statistical difference between Groups I and II, 
however Group III presented with significantly less inflammatory infiltration than the other two groups.

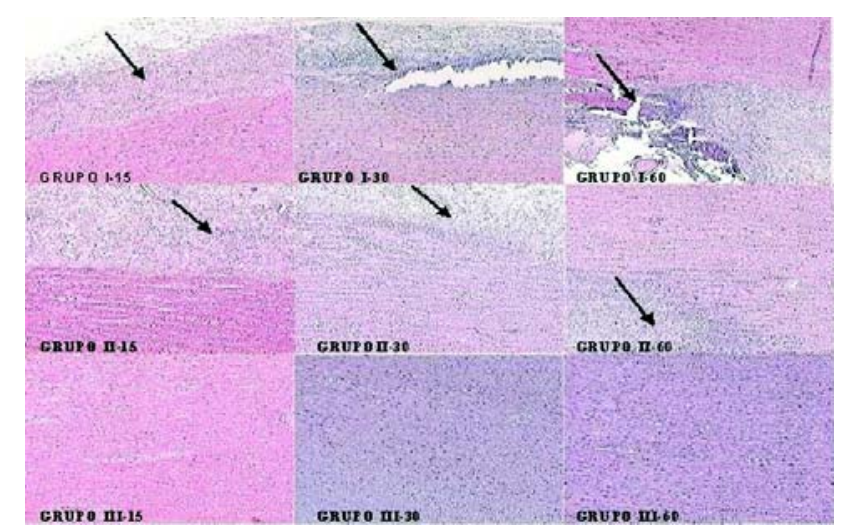

Fig. 1 - Photomicrography of aortic conduits of the three groups studied in the three periods observed (hematoxylin \& eosin $100 x$ ). In Group I there is an increase of the inflammatory infiltrates to the center of implant as the time passed leading to rupture of the matrix fibers. In Group II invasion of infiltrates inside the implant was not observed. In Group III there was no evidence of mononuclear cells

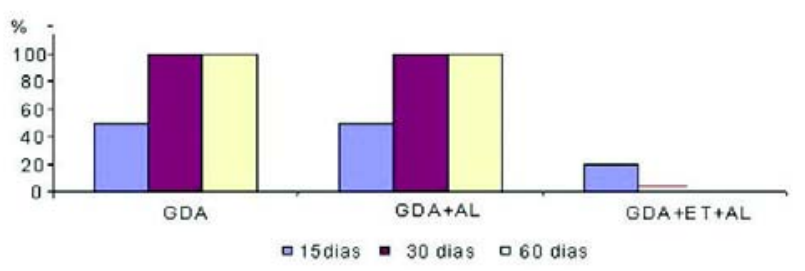

Fig. 2 - Percentage of intense inflammatory reaction in the three groups studied over time

\section{Analysis of the calcification of the conduits as seen using alizarin staining at $\mathrm{pH} 4.2$ \\ Group I}

After 15 days, a large number of calcium phosphate crystals were already visible. At 30 days, there were many spots of calcification, starting at the edges and extending throughout the tissue. At 60 days, the tissue was totally calcified.

\section{Group II}

At 15 days, there were some small scattered spots of calcification stained in red. After 30 days, the spots of calcification were larger than in the previous period however they continued to be spots. Even at 60 days of evolution the calcification remained slight.

\section{Group III}

At 15 days of evolution, there was no evidence of calcification. At 30 days, calcification was still not obvious. Even at 60 days, there was no evident calcification. Occasionally, a spot of calcification would be seen at the nucleus of the cells (Figure 3).

\section{Morphometric analysis of the calcification of conduits (alizarin staining at $\mathrm{pH} 4.2$ ) \\ Morphometry of the calcification of the aortic conduits of the three groups is illustrated in Figure 4.}

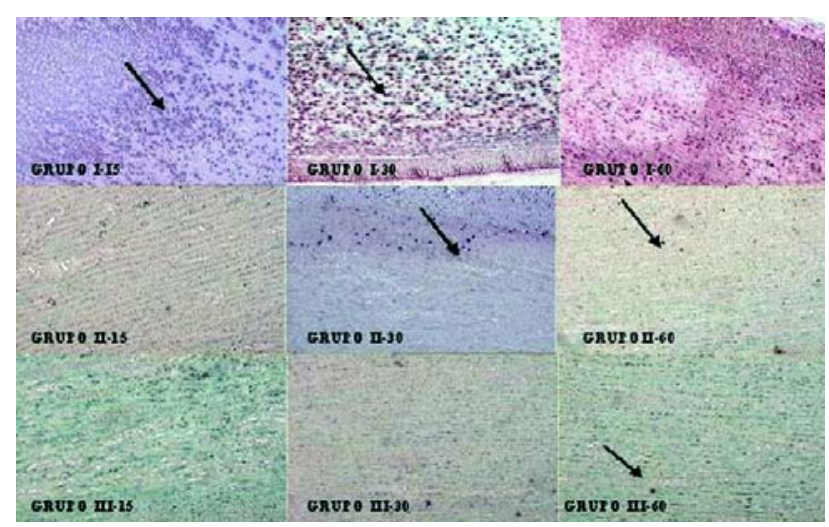

Fig. 3 -Photomicrographies of aortic conduits of the three groups assessed in the three study periods (alizarin 100x), In Group I there was calcification of all the implant after 15 days of evolution. In Group II disperse foci were observed. In Group III foci of points of calcification were observed at the end of the period

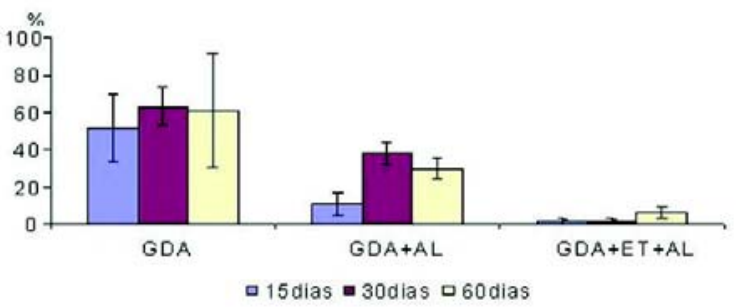

Fig. 4-Percentage of calcification in the three groups studied over time: morphometric analysis 
Group I presented with higher averages of calcification. In the Group treated with aluminum (Group II), when compared with Group I, the difference in the levels of calcium were not statistically significant (p-value $=0.0864)$. In the Group treated with ethanol and aluminum (Group III), the levels of calcification were significantly lower than both Group I (p-value = 0.0143) and Group II (p-value = 0.0090).

\section{Analysis of the calcification of the conduits using alizarin staining at $\mathbf{p H} 7.0$ \\ Group I}

At 15 days, many scattered areas of fine calcification were observed. It was noted that, different to phosphate, the calcium salts were small crystals. At 30 days of evolution, the presence of many areas of calcification were seen that were larger than the previous period. The conduits were much calcified, which was evidenced by deposits of calcium oxalate crystals.

\section{Group II}

After 15 days, the beginning of a process of calcification was seen with small areas stained in red. At 30 days, a few spots of calcification were observed. At 60 days, spots of calcification were observed formed by the deposit of very small crystals of calcium oxalate.

\section{GroupIII}

During the 15, 30 and 60-day periods no calcification was evident (Figure 5).

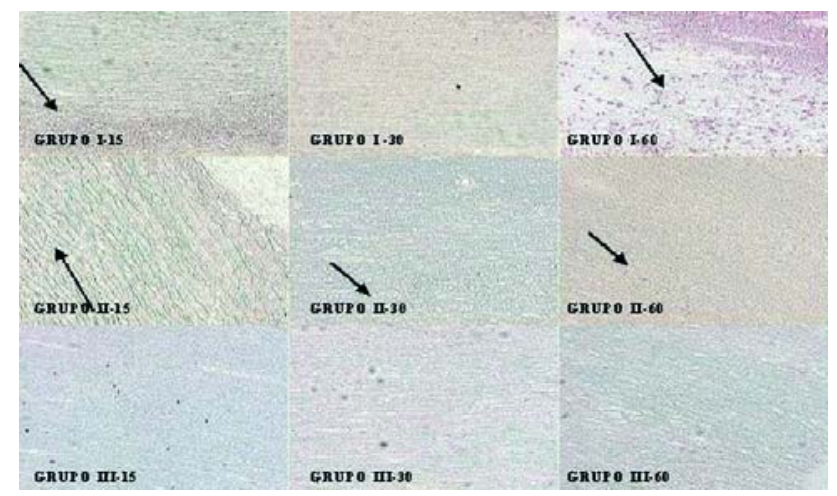

Fig. 5 - Photomicrographies of aortic conduits of the three groups studied at specific observational times (alizarin 100x), In Group I progression of calcification was observed with time (calcium oxalate crystals). In Group II little calcification was observed but without modifying the integrity of the extracellular matrix. In Group III there is total absence of calcification over all periods

\section{Morphometric analysis of the calcification of conduits (alizarin staining at pH 7.0)}

Morphometry of calcification of the aortic conduits of the three groups is illustrated in Figure 6.

Group I presented with the greatest amounts of calcification. In the group treated with aluminum (Group II) there was significantly less calcium when compared with Group I (p-value $=0.0143$ ). The group treated with ethanol and aluminum (Group III) was the group that presented with the lowest amount of calcium which was statistically significant when compared with Group I (p-value = 0.0143) and Group II (p-value 0.0090).

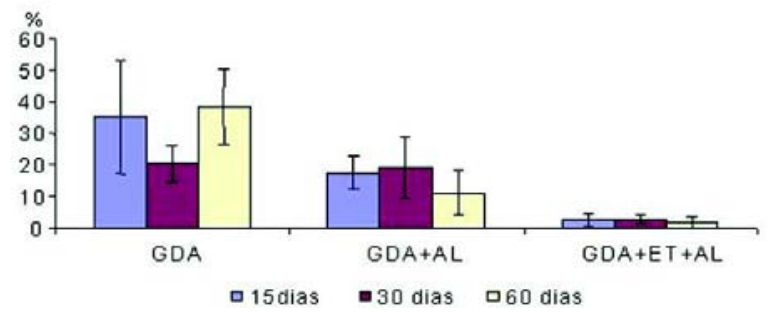

Fig. 6 - Morphometric analysis of the calcification of conduits in the three study periods

\section{Analysis of calcification of the conduits by atomic absorption spectrometry \\ Group I}

In this group, it was observed that the levels of calcium increased progressively. The mean quantity of calcium was $1.56 \pm 0.64 \mathrm{mg} / \mathrm{g}$ of tissue at 15 days, followed by $2.93 \pm 0.58$ $\mathrm{mg} / \mathrm{g}$ at 30 days and $3.80 \pm 0.79 \mathrm{mg} / \mathrm{g}$ at 60 days.

\section{GroupII}

In this group the mean calcium levels were $1.79 \pm 0.20$ $\mathrm{mg} / \mathrm{g}$ at 15 days, $1.07 \pm 0.25 \mathrm{mg} / \mathrm{g}$ at 30 days and $1.68 \pm 0.40$ $\mathrm{mg} / \mathrm{g}$ at 60 days.

\section{Group III}

In this group the mean calcium levels were $1.56 \pm 0.37$ $\mathrm{mg} / \mathrm{g}$ at 15 days, $1.01 \pm 0.06 \mathrm{mg} / \mathrm{g}$ at 30 days and $1.44 \pm 0.52$ $\mathrm{mg} / \mathrm{g}$ at 60 days.

The levels of calcification observed by atomic absorption spectrometry showed that there were significant differences between Group III (p-value = 0.0143) and Group II (p-value $=0.0143$ ) in respect to Group I but not between Group III in relation to Group II (p-value $=0.3472)$. These data are illustrated in Figure 7. 

in GDA

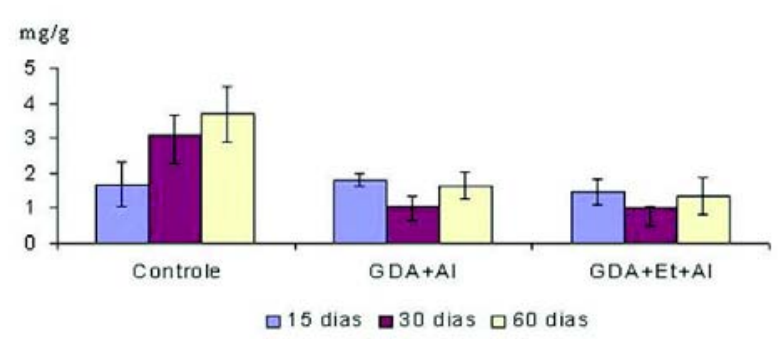

Fig. 7 - Analysis by spectroscopy of atomic absorption of calcification in the three groups studied over time

\section{DISCUSSION}

It is well known that new techniques for the prevention of calcification of biological tissues used in the manufacture of heart valve prostheses should be adequately tested in animal experimentation before being utilized clinically [9].

From a practical point of view, it is recommended that the initial evaluation is performed in the most simple and cheap models, passing to more complex experiment models in subsequent phases [10]. Our study represents the initial evaluation of the efficiency of ethanol combined with aluminum chloride in the prevention of calcification of porcine aortic walls, and for this implantation of fragments of tissues was made under the skin of rats.

Similar to other authors, we chose rats from the SpragueDawley breed as they present with greater inflammatory responses and more intense calcification when compared to rats from the Wister linage [11]. Additionally, younger animals of only three-months of age were used as their calcium metabolism is much more active than old rats.

The mechanism of action of ethanol as an anticalcifying agent is multifactorial and is still not completely understood.

Vyavahare et al. [12] demonstrated that treatment with $80 \%$ ethanol for 24 hours of porcine valve cuspids previously fixed in GDA, caused changes in the configuration of collagen fibers which makes them more resistant to digestion by collagenase, as well as altering the penetration of plasmatic proteins and lipids into valve cuspids, significantly reducing the absorption of cholesterol. When implanted under the skin of rats for 60 days, valve cuspids treated using GDA present with very high calcification (236 $\pm 6 \mu \mathrm{g} / \mathrm{mg}$ of tissue), whilst those treated with GDA and ethanol presented with no calcification, calcium levels remained similar to those observed before implantation (1.86 $\pm 0.29 \mu \mathrm{g} / \mathrm{mg}$ of tissue). These findings were, subsequently, confirmed in a circulation model using sheep, where calcification of the cuspids of mitral prostheses was not observed after 150 days of evolution.

Our research group at TUC-PR has been studying alternative chemical treatments for the prevention of calcification of biological tissue, including the use of ethanol. Studies performed by Soncini da Rosa et al. [8] proved that ethanol was efficient to prevent calcification of valve cuspids implanted subcutaneously in rats for up to 60 days.

Apart from that ethanol, other substances have also proved useful as anticalcifying agents for porcine valve cuspids however they were not efficient to inhibit calcification of aortic wall. This is due to the great quantity of elastin present in the aortic wall exhibiting a different calcification mechanism to the one observed in valve cuspids, where the tissue consists predominantly of collagen fibers.

More recently, Clark et al. [13] demonstrated that the chemical treatment of aortic walls with aluminum chloride was efficient to prevent their calcification. The effects of aluminum are related to its binding with the elastin, which causes a permanent structural alteration, resulting in resistance to calcification. Other effects of the aluminum include an inhibition of the activity of alkaline phosphatase, of elastolysis mediated by metalloproteinases, as well as regulation of Tenascin $C$ protein, present in the extracellular matrix of aortic walls.

According to Bailey et al. [14], metalloproteinase of the matrix is released by the action of the cells of the inflammatory infiltrate, causing digestion of fibers by elastolysis. This, in turn exposes negatively charged binding sites, where deposit of the calcium ion occurs.

Our study represents a continuation of the work initiated by Soncini da Rosa et al. [8] and aims to obtain a combination of chemical treatments that may inhibit calcification of porcine aortic walls previously fixed in GDA. Thus, our primordial object was to test the efficiency of aluminum chloride alone and in combination with ethanol on the arterial wall.

Similar to the findings of Clark et al. [15] and Ogle et al. [16] our results demonstrate that the use of $\mathrm{ALC1}_{3}$ in isolated, when compared to the Control Group, was efficient in reducing calcification of porcine aortic walls. This was evidenced both by the measurement of calcium levels by spectroscopy and by alizarin stains at pHs of 4.2 and 7.0. However, detailed analyses of histological findings including the morphometry of calcium deposits in alizarin stains showed that the association of $\mathrm{ALCl}_{3}$ and ethanol resulted in less inflammatory infiltrates and better preservation of the extracellular matrix than in the group treated with $\mathrm{ALCl}_{3}$ alone. This was probably due to a synergic action of the 
two agents, which resulted in a more stable and biocompatible tissue.

Although most studies related to calcification of valve prosthesis use Von Kossa stain, in our studies we chose alizarin as it can be used at specific pHs and differentiate calcification caused by calcium oxalate crystals and that caused by calcium carbonate or phosphate. As the process of calcification is multifactorial, the use of more specific techniques may provide more detailed information to better understand the mechanisms involved and to develop more efficient methods for its prevention,

In publications consulted for this work, only the study by Vyavahare et al. [17] used alizarin and even so, only at a $\mathrm{pH}$ of 7.0. Reviewing the literature, we verified that our study is the first that utilizes this stain at pHs of 4.2 and 7.0.

Moreover, the morphometry of histology slides using alizarin stain was important to measure the calcification more precisely, when compared to the more subjective practice of simply observing the slides.

By detailed analysis of our findings, we can postulate the presence of at least two important mechanisms of calcification. The first results from the harmful effects of inflammatory infiltrates in the extracellular matrix and the second is due to the chemical affinity of ionic calcium at binding sites of molecules of the matrix. Thus, we can demonstrate calcium deposits both in areas directly related to inflammatory infiltrates and in damaged areas of the matrix as well as in distinct well-preserved areas of the matrix.

The morphology of these calcium deposits differ depending on the mechanism demonstrating the multifactorial characteristics of the process which can only be identified by the use of alizarin stains at different pHs.

Carpentier et al. [2] performed a classical study evaluating the biological interactions in patients who were submitted to valve replacement surgeries. They demonstrated that the presence of inflammatory cells in valve tissue was associated with a greater incidence of degeneration and calcification. Schoen et al. [18] also demonstrated that heart valve prostheses induce immunological reactions and that the cells found in the valve tissue are immunocompetent and capable of destroying the tissue. Our study unequivocally demonstrated that the association of ethanol with aluminum chloride was capable of reducing the inflammatory infiltrates in comparison to the Control Group.

Despite of our results being very promising, some aspects still need to be elucidated before this methodology can be extrapolated for clinical use.

Ogle et al. [16] demonstrated excellent results in a model of rats similar to the current study, but, when tested in a circulation model using sheep, the results were not as expected with accentuated calcification of the valve cuspids. Later, Clark et al. [15] demonstrated that when the valve cuspids were submitted to very long periods exposed to aluminum, calcification occurred, however, when the period was short, the cuspids remained free of calcification. Therefore, our research line needs to be continued with tests in sheep over long observational periods. Moreover, our findings demonstrated that occasionally the calcium deposits are initiated in cellular remains of the matrix. Therefore, decellularization may be an important adjunct to protect these prostheses against calcification and should also be evaluated in the future.

It is important to stress that high concentrations of aluminum can be toxic and it is necessary to include in these studies an assessment not only of plasmatic levels of aluminum, but also their eventual deleterious effects in the diverse organs of experimental animals.

Taking into account the advantages of the use of porcine prostheses implanted with the technique of total aortic root replacement, the use of chemical treatments that delay or eliminate calcification are essential, not only in respect to the cuspids, but also of arterial walls. The results reported here suggest that the combination of ethanol with aluminum chloride may be an excellent alternative and eventually be used in the clinical practice.

\section{CONCLUSION}

Treatment with aluminum chloride reduces calcification of fragments of porcine aortic wall preserved in GDA implanted in the subcutaneous tissue of young rats. The combined use of ethanol with aluminum chloride was even more efficient to inhibit calcification and also to reduce the inflammatory reaction.

\section{REFERENCES}

1. Ross DN, Radley-Smith R, Somerville J. Pulmonary autograft replacement for severe aortic valve disease. Br Heart J. 1969;31(6):797-8.

2. Carpentier A, Lemaigre G, Robert L, Carpentier S, Dubost C. Biological factors affecting long-term results of valvular heterografts. J Thorac Cardiovasc Surg. 1969;58(4):467-83. 
3. Ionescu MI, Pakrashi BC, Mary DA, Bartek IT, Wooler GH, McGoon DC. Long-term evaluation of tissue valves. J Thorac Cardiovasc Surg. 1974;68(3):361-79.

4. Braile DM, Bilaqui A, Ardito RV, Greco OT, Garzon SA, Nicolau JC, et al. Bioprótese cardíaca de pericárdio bovino. Arq Bras Cardiol. 1982;39(4):247-57.

5. Girardot MN, Torrianni M, Dillehay D, Girardot JM. Role of glutaraldehyde in calcification of porcine heart valves: comparing cusp and wall. J Biomed Mater Res. 1995;29(7):793-801.

6. Gott JP, Girardot MN, Girardot JM, Hall JD, Whitlark JD, Horsley WS, et al. Refinement of the alpha aminooleic acid bioprosthetic valve anticalcification technique. Ann Thorac Surg. 1997;64(1):50-8.

7. Abolhoda A, Yu S, Oyarzun JR, McCormick JR, Bogden JD, Gabbay S. Calcification of bovine pericardium: glutaraldehyde versus No-React biomodification. Ann Thorac Surg. 1996;62(1):169-74.

8. Soncini da Rosa GR, Costa FDA, Mesquita L, Costa ISEA. Estudo comparativo da eficácia do etanol e do ácido L-glutâmico na prevenção da calcificação das cúspides e parede aórtica porcina: estudo experimental em ratos. Rev Bras Cir Cardiovasc. 2002;17(2):148-59.

9. Levy RJ, Schoen FJ, Flowers W, Staelin T. Initiation of mineralization in bioprosthetic heart valves: studies of alkaline phosphatase activity and its inhibition by $\mathrm{AlCl} 3$ or FeCl3.preincubations. J Biomed Res. 1991;25(8):905-35.

10. Schoen FJ, Levy RJ, Hilbert SL, Bianco RW. Antimineralization treatments for bioprosthetic heart valves. J Thorac Cardiovasc Surg. 1992;104(5):1285-8.
11. Daamen WF, Nillesen ST, Hafmans T, Veerkamp JH, van Luyn MJA, van Kuppevelt TH. Tissue response of defined collagenelastin scaffolds in young and adult rats with special attention to calcification. Biomaterials. 2005;26(1):81-92.

12. Vyavahare N, Hirsch D, Lerner E, Baskin JZ, Schoen FJ, Bianco $\mathrm{R}$, et al. Prevention of bioprosthetic heart valve calcification by ethanol preincubation. Circulation. 1995;95(2):479-88.

13. Clark JN, Ogle MF, Ashworth P, Bianco RW, Levy RJ. Prevention of calcification of bioprosthetic heart valve cusp and aortic wall with ethanol and aluminium chloride. Ann Thorac Surg. 2005;79(3):897-904.

14. Bailey M, Xiao H, Ogle M, Vyavahare M. Aluminum chloride pretreatment of elastin inhibits elastolysis by matriz metalloproteinases and leads to inhibition of elastin -oriented calcification. Am J Pathol. 2001;159(6):1981-85.

15. Clark JN, Ogle MF, Ashworth P, Bianco RW, Levy RJ. Prevention of calcification of bioprosthetic heart valve cusp and aortic wall with ethanol and aluminium chloride. Ann Thorac Surg. 2005;79(3):897-904.

16. Ogle MF, Kelly SJ, Bianco RW, Levy RJ. Calcification resistence with aluminum-ethanol treated porcine aortic valve bioprostheses in juvenile sheep. Ann Thorac Surg. 2003;75(4):1267-73.

17. Vyavahare N, Ogle M, Shoen FJ, Levy RJ. Elastin calcification and its prevention with aluminum chloride pretreatment. Am J Pathol. 1999;155(3):973-81.

18. Schoen FJ. Are immune mechanisms important in tissue heart valve failure? A debate. J Heart Valve Dis. 2001;10(4):458-9. 